\title{
Weather Factors in Different Growing Periods Determine Inter-annual Change in Growth of Four Sphagnum Species: Evidence From an Eight-year Study
}

Natalia G. Koronatova ( $\nabla$ koronatova@issa-siberia.ru )

Institute of Soil Science and Agrochemistry: Institut pochvovedenija i agrokhimii https://orcid.org/0000-0002-0557-0083

Natalia P. Kosykh

Institute of Soil Science and Agrochemistry: Institut pochvovedenija i agrokhimii

Ekaterina A. Saib

Institute of Soil Science and Agrochemistry: Institut pochvovedenija i agrokhimii

Vera A. Stepanova

Institute of Soil Science and Agrochemistry: Institut pochvovedenija i agrokhimii

Evgenia K. Vishnyakova

Institute of Soil Science and Agrochemistry: Institut pochvovedenija i agrokhimii

Gustaf Granath

Uppsala University: Uppsala Universitet

\section{Research Article}

Keywords: Functional traits, Primary productivity, Meteorological variables, Peatland, Peat moss

Posted Date: January 25th, 2022

DOI: https://doi.org/10.21203/rs.3.rs-1271460/v1

License: (c) (i) This work is licensed under a Creative Commons Attribution 4.0 International License. Read Full License 


\section{Abstract}

The growth of peat mosses is crucial for the functioning and carbon uptake and storage in high latitude peatlands. Nevertheless, a little is known on the response of Sphagnum functional traits and primary production to weather fluctuations. Here we investigated if weather variables affect Sphagnum growth differently across the season. An eight-year study was carried out in a mire complex in the southern taiga of Western Siberia. We collected weather data, and data on functional traits (length increment, increment weight, capitulum numerical density and capitulum weight) and assessed primary productivity of four Sphagnum species growing in raised bogs and poor fens. Overall, growing season averages of weather variables were often as good predictors of Sphagnum functional traits and productivity as early or late seasonal averages, but not necessarily for the same variables. The most important factors were those related moisture conditions. The more sensitive traits to weather fluctuation were length increment (for $S$. magellanicum, S. angustifolium, S. fallax) and numerical density (for $S$. fuscum). Primary productivity of $S$. fuscum and $S$. magellanicum were the highest under warm and wet conditions with $S$. fuscum being less sensitive to the weather; productivity of $S$. angustifolium increased under cool and wet conditions; and productivity of $S$. fallax was the highest under dry weather. Diversity in interspecific response to weather fluctuations may result in high peatland resistance towards environmental variability, and thereby maintaining a stable Sphagnum productivity in time across the mire complex.

\section{Introduction}

Sphagnum species are the main peat formers in northern mires (Chapin III et al. 1996). Sphagnum biomass and growth reflect the local environmental conditions (Bengtsson et al. 2016); and therefore, their performance can serve as an indicator of regional climate change (Gignac and Vitt 1994). A deeper understanding of weather effects on moss productivity is essential for modelling plant growth, and ultimately carbon sequestration, in a changing climate. Examining primary productivity and growth of Sphagnum and their relationship to meteorological factors is especially important for Western Siberia, which is the largest peatland complex in the world (Gorham 1991). Here, Sphagnum-dominated peatlands cover $6 \cdot 10^{5} \mathrm{~km}^{2}$ (Smith et al. 2004) including $1.4 \cdot 10^{5} \mathrm{~km}^{2}$ in the southern taiga (Peregon et al. 2008), and this area contributes significantly to the global carbon cycle. Earlier attempts of modelling Sphagnum growth using climatic data (reviewed in Bengtsson et al. 2021) have focused on different spatial and temporal scales, or number of species. However, detailed studies following many species over a long time period with varying weather are still lacking. Such data are particularly important from a globally important peatland area like Western Siberia.

Climate directly affects moss distribution, abundance, and performance (Gignac and Vitt 1994; Oke and Hager 2017). Moss growth is uneven over years (Maksimov 1982; Beckéus 1988; Moore 1989; Lindholm and Vasander 1990; Grabovik and Nazarova 2013) and strongly depends on inter-annual weather variability under the same climatic zone (Asada et al. 2003). Crucial factors affecting moss growth on a global scale are temperature, precipitation and photosynthetically active radiation (Bengtsson et al. 2021; Gunnarsson 2005; Loisel et al. 2012). Sphagnum growth begins at a temperature slightly above $0^{\circ} \mathrm{C}$ 
(Asada et al. 2003; Moore et al. 2006), and rising temperatures during the growing season cause increases in moss length growth and productivity (Breeuwer et al. 2008; Grabovik and Nazarova 2013; Krebs et al. 2016). On the other hand, if water availability is low, high temperature can lead to drying of the active apical part of the Sphagnum moss (i.e. the capitulum) and reduce photosynthesis and productivity (Schipperges and Rydin 1998; Deane-Coe et al. 2015). Experiments with elevated temperatures have, for example, reported no positive effect on Sphagnum growth (e.g. Bu et al. 2011).

On a local scale, water availability is likely the strongest factor for moss productivity (Maksimov 1982; Beckéus 1988; Lindholm 1990; Asada et al. 2003; Waddington et al. 2015). Water is provided from two sources: drawn from below (water table) and precipitated from above. Laboratory experiments have revealed a positive correlation between shallower water tables and photosynthesis, growth and moss productivity (Weltzin et al. 2001; Robroek et al. 2007, 2009; Nijp et al. 2014). In field experiments, the height above water table (HWT) appears to affect Sphagnum growth on individual mires (Maksimov 1982; Mulligan and Gignac 2001; Yazaki and Yabe 2012; Graham and Vitt 2016); however, HWT has been reported to be less significant in long-term multispecies investigations (Weltzin et al. 2001; Bengtsson et al. 2016, 2021). Instead, summer precipitation may be a stronger predictor of Sphagnum linear growth and productivity (Weltzin et al. 2001; Kosykh et al. 2017a). Furthermore, the temporal distribution of precipitation is important for moss growth. Frequent rains have a positive effect because they maintain the active top-part of the moss wet and thereby counteract a low HWT (Beckéus 1988; Robroek et al. 2009; Nijp et al. 2014; Krebs et al. 2016). In addition, a negative effect of mean length of rain free periods on moss growth supports the idea of also investigating the precipitation pattern and not only focus on the annual sum (Bengtsson et al. 2021).

In the boreal zone, Sphagnum growth fluctuates within the growing season. The growth pattern typically has a peak in the beginning of the growing season followed by decreased growth in the summer, and sometimes a second peak late in the season (Maksimov 1982 Kosykh et al 2017a, b). However, the growth pattern likely shifts between years due to differences in weather. For example in the Bakchar mire (Western Siberia), the maximal mean month air temperature takes place in June, July or August depending on year and ranges from 18 to $20^{\circ} \mathrm{C}$; precipitations fluctuate from 20 to $160 \mathrm{~mm}$ a month during the growing season of several years (Dyukarev and Golovatskaya 2013). Regardless of the weather variation over the season, water table is close to the moss surface in May and June and subsequently it drops and changes during the summer (Dyukarev and Golovatskaya 2013). Snow cover and frost depth, which determines the amount of melt water, is an essential source of water for bryophytes at high latitude in the spring and early summer (Küttim et al 2020b). In the Bakchar mire, seasonal frost penetrates down to $50-53 \mathrm{~cm}$ (Koronatova 2019) and it is likely a substantial source of melt water for mosses as the snowpack melts in May while soil frost melts in May or June.

Sphagnum responses to temperature, precipitation, and HWT changes within and between years differ among species and ecological groups. Sphagnum species are adapted to different HWT, which has resulted in differences in functional trait values (Laing et al. 2014; Bengtsson et al. 2020). Stable length increment is typical for hummock-dwelling species such as S. fuscum (Lindholm and Vasander 1990; 
Mulligan and Gignac 2001; Asada et al. 2003; Robroek et al. 2007; Granath et al. 2010) that are more resistant to environmental change (Bu et al. 2013). Species growing closer to the water table (i.e., lawns and hollows), e.g., S. magellanicum and $S$. angustifolium, can have higher growth rates under wet conditions but dry out easier, which strongly reduces growth (Mulligan and Gignac 2001; Robroek et al. 2007; Mazziotta et al. 2019). We thus, need to improve our understanding of how traits related to growth and productivity which differ between species, such as length increment, its weight and shoot density (Laing et al. 2014; Hájek 2009), respond to within- and between-year variation in weather.

It is clear that weather factors drive variation in Sphagnum productivity within and between years. For within year variation, a separation between the early and the late period of the growing season seems most reasonable. High availability of soil melt water from snow and frozen peat observed in May and June is inherent for the early season. Intermittent availability of soil capillary water from varying HWT is an attribute of the late season. Temperature, precipitation, number of rainy or dry days are variables that vary during the growing season and between years. We assume that these variables affect the magnitude of Sphagnum growth every year and can act in opposite directions early and the late in the season, depending on availability of soil moisture. For example, a high temperature should promote intensive growth when peat is saturated with water, but the same temperature desiccates mosses and stops growth if water replenishment through rain or capillary water is low or absent. Precipitation promotes moss growth if peat moisture is low and acts contrarily, as a moss growth inhibitor, if water availability is high. In the latter case, reduction in light due to cloudiness can further decrease carbon uptake (Nijp et al. 2015). Taken together, a significant portion of moss growth and production are realized during the most favorable periods of the growing season, or the most favorable years, however, the timing can vary between species.

Here, we tested the hypothesis that weather variables associated with the early or the late season are stronger predictors of the value of annual Sphagnum functional traits and productivity compared to the growing season average. First, we quantified inter-annual variability in functional traits (i.e., length increment, increment weight, capitulum density and weight) and productivity of the most common and functionally important bryophytes, Sphagnum fuscum, S. magellanicum, S. angustifolium, and S. fallax, in two typical for this region but contrasting habitats, raised bogs and poor fens. Second, we examined the response of moss functional traits and productivity to weather variables associated with the early and the late season as well as to entire season. Third, we investigated interspecies and habitat difference in moss responses to weather variables to test if Sphagnum species and habitats have different climate sensitivity (Robroek et al 2017; Jassey and Signarbieux 2019; Küttim et al. 2020a; Bengtsson et al. 2021).

\section{Materials And Methods Study sites}

Our field study was carried out in the Bakchar mire, which is located in the southern taiga subzone of Western Siberia $\left(56^{\circ} 51^{\prime} \mathrm{N}, 82^{\circ} 51^{\prime} \mathrm{E}\right)$. The mire complex occupies more than 1000 square kilometres and 
includes treed and open raised bogs and poor fens with a 2-m peat deposit. The climate is continental, mean monthly temperatures are $-17.7^{\circ} \mathrm{C}$ in January and $+19.1^{\circ} \mathrm{C}$ in July, and mean annual precipitation is $539 \mathrm{~mm}$ (Hydrometeorological Center 2020). In the raised bogs, the dominant plants are sparse trees, Pinus sy/vestris of 1-3 m height and 40-60 years of age; dwarf shrubs, Rhododendron tomentosum (syn. Ledum palustre) and Chamaedaphne calyculata; and mosses, Sphagnum fuscum, S. angustifolium and S. magellanicum aggregate (now divided into $S$. medium and S. divinum according to Hassel et al. 2018 but in this study we use S. magellanicum agg.), and rarely S. balticum. In the poor fens, the dominant plants are sedges, Carex rostrata; and mosses, $S$. fallax, other mosses are less common (S. riparium, S. obtusum, S. angustifolium) or found sporadically (S. lindbergii).

\section{Measurement of functional traits and annual net productivity calculation}

For functional traits we quantified Sphagnum length increment (or height increment, $\mathrm{LI}, \mathrm{mm} \cdot \mathrm{yr} \mathrm{r}^{-1}$ ), lengthspecific stem biomass i.e. increment weight (IW, $\left.\mathrm{g} \cdot \mathrm{mm}^{-1} \cdot \mathrm{dm}^{-2}\right)$, numerical density i.e. capitula per unit area (ND, $\mathrm{dm}^{-2}$ ) and capitulum weight (or capitulum mass, CW, mg). We followed Laing et al. (2014) and considered Sphagnum LI, IW, ND as canopy traits, and CW as a shoot trait. According to Laing et al. (2014) LI of Sphagnum individuals signify stem elongation and it is controlled by water availability gradient with maximal elongation in wet habitats. $\mathrm{CW}$ controls photosynthesis and growth at the individual shoot level. IW, ND and CW are attributed to habitat and water table gradient: shoot and capitulum mass decreases whereas numerical density increases with increasing height above water table (Laing et al. 2014). The plastic response of capitulum size and numerical density to water-table depth is a mechanism of by moisture maintaining in capitula high above the water table (Rydin 1993).

The method of moss LI measurement depended on carpet density and direction of growth. We measured the LI of S. fuscum and S. magellanicum that had dense carpets and small vertical growth using the brush-wire method (Rydin and Jeglum 2013), which is a modification of the cranked wire method (Clymo 1970). The method implied measuring the length of a wire fixed in a moss carpet. To measure the LI of S. fallax and S. angustifolium we employed individual markings on shoots (Kosykh et al. 2008). The method was relevant for measuring the LI of species with high growth, not the upright shoot position and loose carpet. The method is a modification of the tied thread method (Clymo 1970). We circled a thin stainless wire around moss shoots below the capitulum without tightening it so that the wire ring laid on moss branches. A foil label attached to the free end of the wire helped in finding the marked plants. In late September or early October, we sampled marked plants and measured the shoot increment above the place of the wire tie (Appendix Fig. S1). The synchronous use of both methods depending on Sphagnum features has been previously reported (Maksimov 1982; Bengtsson et al. 2016).

To evaluate IW, ND and CW, we usually sampled 3-4 cores of each Sphagnum species. We applied a hard plastic cylinder with a square of $16.6 \mathrm{~cm}^{2}$ at the same plots or at patches adjacent to where the LI was measured. Both the capitula and 3-cm stem sections below the capitula were collected; the number of 
capitula were counted. To evaluate IW, a 3-cm stem section of each capitulum was measured and cut off. Therefore, IW is not the same as the bulk density for a $3-\mathrm{cm}$ section as a bulk density sample may include shoots longer than $3 \mathrm{~cm}$ if they are bend, as well as dead Sphagnum individuals. Then these moss fractions were dried to a constant weight at $60^{\circ} \mathrm{C}$ and weighed.

Sphagnum aboveground net productivity (ANP, $\mathrm{g} \cdot \mathrm{m}^{-2} \cdot$ year $^{-1}$ ) was calculated as the annual $\mathrm{LI}(\mathrm{mm})$ multiplied by the IW $\left(\mathrm{g} \cdot \mathrm{mm}^{-1} \cdot \mathrm{dm}^{-2}\right)$ and expressed per square meter.

\section{Experimental design}

Species were chosen to represent the most common and functionally important bryophytes, $S$. fuscum, $S$. magellanicum, $S$. angustifolium, and $S$. fallax, in two typical for this region but contrasting habitats, raised bogs and poor fens. In addition to the four species we also measured traits in S. balticum, S. riparium, S. obtusum. However, they were not measured over many years and we therefore only present their raw data, which also is available together with all other data at the Mendeley Data repository (https://doi.org/10.17632/6d3sgzmdxp.2).

In the raised bog, $S$. fuscum dominated the moss carpet and S. magellanicum and $S$. angustifolium were co-dominants. The surface of the bog had typical hummocks and hollows where Sphagnum species occupied different positions according to their microtopographical niche (Rydin and Jeglum 2013, Bengtsson et al. 2016). At our site, S. fuscum grew on the most elevated microtopographical position, while $S$. magellanicum and $S$. angustifolium occurred in hollows and low hummocks. We established permanent monospecific $0.25 \mathrm{~m}^{2}$ plots of $S$. fuscum on hummocks as well as S. magellanicum and $S$. angustifolium on low hummocks and hollows; four plots per species and separated by $100 \mathrm{~m}$. Mean hummock height of the established plots was $32 \pm 7 \mathrm{~cm}$ (mean $\pm S E$ ) for $S$. fuscum and $13 \pm 3 \mathrm{~cm}$ for both $S$. magellanicum and $S$. angustifolium. We placed 3 to 5 brush-wires ( $S$. fuscum and $S$. magellanicum) or markings on shoots (S. angustifolium) per plot and species. In the first years of the study, we observed that some markings disappeared when being buried deep by the growing moss carpet. Therefore, we tripled the number of markings on shoots since 2016. The total number of replicates per year were 12-14 for S. fuscum, 10-18 for S. magellanicum, and 3-30 for S. angustifolium.

In the poor fen, the even surface and absence of trees and dwarf shrubs created a homogeneous environment for $S$. fallax growing in different points of the mire. Here, we set one monodominant plot of S. fallax of $10 \times 10 \mathrm{~m}$ size and placed from half to few dozens of markings on shoots per year. Eventually, the number of replicates were 3-18 per year after some portion of markings were immersed in the moss carpet.

Sphagnum growth measurements were carried out over eight years (2013-2020). In 2013, brush wires and markings on shoots were established in the spring after freezing-thawing had stopped (late May) and were re-established in late September. In the spring of the next year, we found out that the mosses did not grow during autumn and that the snowpack did not violate the marking position over the winter. In 
subsequent years, we visited study sites in late September or early October to sample and set new wires and markings. At the autumn visit, we also measured the heights of hummocks where wires and markings were set in the raised bog and the HWT in the poor fen. We also extracted 3 to 4 Sphagnum cores of each Sphagnum species per year. A few cores were lost between 2013 and 2015, which reduced the sample size, and we also lost some LI measurements for S. angustifolium in 2013 and 2015.

\section{Weather data}

Weather data were extracted from the weather station "Bakchar", which is situated $50 \mathrm{~km}$ from the study site (Raspisanie pogody 2019).

As Sphagnum growth starts slightly above $0^{\circ} \mathrm{C}$ (Lindholm 1990; Asada et al. 2003; Moore et al. 2006; Küttim et al. 2020a), we considered spring days with three consecutive positive minimum daily temperatures followed by a period with rising temperature as the beginning of the growing season. We considered the first three consecutive days with negative minimum daily temperatures in the autumn as the end of the growing season. Over the observed years, the growing season started from the middle of April to the end of May and ended from the early to the late September (Appendix Table S1). According to water table changing and period of frozen peat melting reported for our study region by Dyukarev and Golovatskaya (2013), we separated growing season weather data into two periods: i) the early growing season, from its beginning to the end of June; and ii) the late growing season from July to its end.

The seven weather variables used in the analyses were the following (Table 1): mean temperature $\left(T_{m}\right.$, $\left.{ }^{\circ} \mathrm{C}\right)$, precipitation $(\mathrm{Pr}, \mathrm{mm})$, number of days with rain (RD, days). Moss productivity has been shown to decrease after three days without rains (Krebs et al. 2016) and moss photosynthesis and respiration are induced during the 2 to 3 days following even small rain events (Strack and Price 2009). Therefore, length of dry period (DD, days) was calculated from the fourth consecutive day without precipitation, and then we added up the calculated days without rain over a period. We used the climatic index $\left(\mathrm{Cl}_{\mathrm{As}}\right)$ proposed by Asada et al. (2003) as it should reflect conditions important for moss growth. We calculated the index value using a simplified formula:

$$
\mathrm{CI}_{\mathrm{As}}=\sum_{i=1}^{n} p_{i} \cdot t_{\max i} / n
$$

where $p$ is precipitation on the ith day, $t_{\max } i$ is maximal daily temperature on the ith day, and $n$ is the number of days. Finally, we used the parameter "precipitation at mean daily temperature above $15^{\circ} \mathrm{C}^{\prime}$ $\left(\mathrm{Pr}_{\mathrm{T} 15}, \mathrm{~mm}\right)$. This parameter was tested because moisture is especially important for mosses in hot 
weather as it prevents the capitulum from drying, which could be particularly important given the continental climate of Western Siberia.

\section{Statistical analysis}

Statistical models were examined for normality and as the residuals did not follow a normal distribution we ran non-parametric tests. To test for yearly and intra-season weather difference, the Kruskal-Wallis non-parametric test was performed separately for each weather variable. Pairwise post-hoc differences within the season were tested by the Mann-Whitney test.

To test for yearly differences in moss functional traits, the Kruskal-Wallis test was performed followed by Mann-Whitney post-hoc pairwise test. To quantify the strength of weather variables predictability of Sphagnum functional traits between growth periods, we applied Spearman's rank correlations. To examine which trait had the largest impact on ANP we performed Pearson's correlation analysis as they showed linear relationships.

We employed principal component analysis (PCA) to explore trait variables explaining interspecies differences.

We employed two-block partial least squares analysis (PLS) to explore how meteorological variables can explain variation in Sphagnum trait values. In short, this method maximizes the covariation between two blocks (i.e., sets of variables) of data where each row has the same id (Rohlf and Corti 2000). Here, the first block included seven weather variables and the second block contained the Sphagnum functional traits.

Differences were considered significant at $P<0.05$. Data analyses were performed using PAST software V. 2.17 (Hammer et al. 2001).

\section{Results}

\section{Inter-annual weather variability}

On average across the study period, the growing season lasted 129 days, and it was particularly long in 2015 (159 days), 2016 and 2020 (160 days). Weather variables showed significant variation between seasons (Table 1). Kruskal-Wallis tests showed that mean temperature $\left(\chi^{2}=10.02, P=0.0066\right)$, precipitation $\left(\chi^{2}=12.54, P=0.0019\right)$ and number of days with rain $\left(\chi^{2}=14.22, P=0.0008\right)$ contributed to intra-season weather differences. Number of days without rain $\left(\chi^{2}=7.91, P=0.0187\right)$ and precipitation at mean daily temperature above $15^{\circ} \mathrm{C}\left(\chi^{2}=9.50, P=0.0087\right)$ differed in the early season, and no difference was found for climatic index (Appendix Table S2). Correlations were detected for a few weather variables within a season (Appendix Table S3) as well as between seasons (Appendix Table S4). 


\section{Inter-year dynamics and interspecific difference of Sphagnum functional traits and productivity}

S. fuscum had the most stable LI over the observed period whereas LI of other species considerably varied from year to year (Fig. 1a,b,c,d; Appendix Table S5). ND of S. fuscum, in contrast, significantly changed between years while this was not observed for the other species (Fig. 1e,f,g,h; Appendix Table S6). No differences were detected in inter-year IW values among all species (Fig. 1i,j,k,l; Appendix Table S7). S. fallax CW significantly varied over the years with its lowest value in 2015 and highest in 2019 but no difference in CW was detected for other species (Fig. 1m,n,o,p; Appendix Table S8). Finally, we found that ANP substantially differed between years for all species (Fig. 1q,r,s,t; Appendix Table S9). ANP of the fen species $S$. fallax was two-fold higher than that of bog species.

Species growing in the bog had lower $\mathrm{LI}$ and $\mathrm{CW}$, with the smallest value being found for S. fuscum. Conversely, S. fuscum had the greatest IW and ND. The PCA revealed two principal components with the first axis defined a tradeoff between CW and ND (Fig. 2) as it has previously been shown by Laing et al. (2014). The first axis was also associated with IW whereas the second axis was associated with LI. Significant interspecific differences were detected between all species for all traits, except for between $S$. fallax and S. magellanicum for ND and CW (Appendix Table S10).

\section{Effects of weather variability on Sphagnum length increment}

Correlations between LIs and weather factors were different between species (Fig. 3). The LI of S. fuscum was almost independent of weather factors. For S. magellanicum, LI was positively correlated with precipitation, especially at high temperature, and the climatic index during both seasonal periods, and even stronger over the entire warm season. Length of dry period negatively affected $S$. magellanicum growth in the early season.

Unlike S. magellanicum, the LI of $S$. angustifolium positively responded to increasing temperature and total precipitation in the early season as well as number of days with rain in the late season. Contrary to the early season, increasing temperature in the late season inhibited $S$. angustifolium LI. Across the entire season, precipitation ( $\mathrm{Pr}$, and $\mathrm{Pr} 15)$ showed a strong positive correlation with $\mathrm{LI}$, while temperature showed a negative effect.

The effects of weather on S. fallax LI were complex across the season. In the early season, higher temperature and number of rain days decreased LI, while precipitation at high temperature increased LI. Late in the season, higher temperature and length of dry period were correlated with increased LI. Similar to the early season, number of days with rain decreased $\mathrm{LI}$ and this was also true for the entire season. Like $S$. angustifolium, the correlation between $S$. fallax $\mathrm{LI}$ and temperature was different depending on the period of the growing season, but with opposite signs compared to S. angustifolium. 
Generally, LIs of all species except $S$. fuscum were sensitive to varying weather variables in different periods, i.e. there was an individual set of significant weather variables controlling LI of these Sphagnum species. For $S$. angustifolium and $S$. fallax weather variables over the entire growing season were less pronounced predictors in contrast to the early or the late season.

\section{Effects of weather variability on Sphagnum increment weight, numerical density and capitulum weight}

In contrast to the LI, the ND of $S$. fuscum depended on many weather factors, but mainly precipitation (Pr and Pr15) and climatic index, with the early and the entire seasons being equally good predictors for ND (Fig. 4). IW was affected by moisture conditions over the growing season, specifically with precipitation in the early season and number of days with rain in the late season. Rising mean summer temperature decreased both S. fuscum ND and IW. Number of days with rain and precipitation at high temperature were predictors positively influencing $S$. fuscum $\mathrm{CW}$.

The ND of S. magellanicum was also to a similar degree controlled by the weather of the entire season as by a specific period. The precipitation including those at high temperature and the number of days with rain affected both ND and IW at similar magnitudes.

IW of $S$. fallax was positively affected by the number of rainy days, and negatively by the length of dry period in the late season. Its CW was negatively correlated with the precipitation and the length of dry period. However, the strongest weather factor affecting CW was mean temperature in the entire season, which correlated positively with $S$. fallax $\mathrm{CW}$.

We did not detect significant effects of weather variables on the CW of $S$. magellanicum, ND of $S$. fallax nor ND, IW and CW of S. angustifolium.

In the early and the entire season, results of 2-block PLS were similar (Fig. 5a, d) indicating the differ response of bog and fen species to weather gradient. The amount of covariance explained by the Axis 1 was $82-83 \%$. In the late season, the amount of covariance explained by the Axis 1 and the Axis 2 were $50 \%$ and $46 \%$, respectively. In the first case, S. fuscum distinguished from other species (Fig. $5 \mathrm{~b}$ ), and in the second case, species were distributed according to the water table gradient (Fig. 5c).

\section{Weather factors controlling Sphagnum ANP}

The primary productivity of moss is a function of $\mathrm{LI}$, IW and ND. The contributions of these functional traits to ANP were species-specific (Table 2). Productivity of $S$. fuscum was mainly determined by IW, while the productivity of $S$. angustifolium and $S$. fallax was mostly influenced by LI. S. magellanicum ANP was almost equally determined by all these traits. 
Correlations between ANP and weather variables illustrated how productivity depends on the weather through changes in growth traits (Fig. 6). ANP of S. magellanicum, S. angustifolium and S. fallax had the same strongest weather predictors as for $\mathrm{LI}$ of these species. ANP of $S$. fallax was also affected by weather variables, such as the climatic index, which was not linked to changes in its functional traits. Contrarily, $S$. fuscum ANP depended less on weather variables. The significant factors affecting $S$. fuscum ANP were also significant for its ND, but to a lesser degree for IW.

Mean growing seasonal temperature was not a significant predictor for $S$. fuscum and S. magellanicum productivity (ANP) whereas it was a strong predictor for $S$. angustifolium $(-0.47)$ and intermediate predictor for $S$. fallax (0.27). Precipitation was one of the strongest predictors, where higher precipitation was associated with greater ANP, either per season or over the entire growing season. However, for the fen-dwelling $S$. fallax precipitation over the entire season was not a good predictor as higher precipitation in the spring increased ANP while higher precipitation in the fall decreased ANP, thereby cancelling out an entire season effect. Climatic index $\left(\mathrm{Cl}_{\mathrm{AS}}\right)$ was of the similar importance as $\operatorname{Pr} 15$ for $S$. fuscum and $S$. magellanicum, while it was a weak or negligible predictor for the other species. The strength of the positive association between the number of rainy days (RD) and ANP increased in the sequence of bog species S. fuscum (no impact) - S. magellanicum - S. angustifolium, which is in accordance with their moisture sensitivity. In contrast, RD decreased ANP for $S$. fallax. Finally, length of dry period (DD) over the entire season decreased ANP for $S$. magellanicum (-0.29), which likely was related to DD early in the season (-0.20). For $S$. fallax, DD increased ANP, and did so strongest in the late season (0.44). Overall, in the early season, Sphagnum productivity of all species intensified with moisture factors ( $\operatorname{Pr}, \operatorname{Pr} 15$ and/or $\mathrm{Cl}_{\mathrm{As}}$ ). In the late season, the impact of these factors decreased for the species except $S$. magellanicum. More dry soil conditions in the late season especially affected to $S$. angustifolium, which reduced ANP under higher mean temperature causing capitulum desiccation and enhanced it under increasing number of rainy days.

\section{Discussion}

This study investigates the hypothesis that weather variables of the early or the late season are stronger predictors of the value of annual Sphagnum functional traits and productivity compared to the growing season average. Weather variables show different correlations with Sphagnum growth depending on the period of the growing season and species. Within-season changes in weather are as important for Sphagnum growth as changes over the entire season, and species differ widely in their responses to such changes. Growing season averages of weather variables are often as good predictors of the functional traits as late or early seasonal means, but not necessarily for the same variables. This indicates the complexity in identifying causal relationships between weather and plant performance.

\section{Trait- and species-specific response of Sphagnum to weather factors}


Numerous studies have shown how Sphagnum length increment changes between years (e.g. Moore 1989, Lindholm et al. 1990, Graham and Vitt 2016). In our 8-year study, large inter-year variation of LI of a lawn-hollow species ( $S$. fallax) and species with a wide ecological niche (S. angustifolium, $S$.

magellanicum) was linked to weather fluctuations. S. angustifolium and S. magellanicum are sensitive to low water availability (Schipperges and Rydin 1998; Mulligan and Gignac 2001; Robroek et al 2007; Strack and Price 2009). Our study shows that for these species, weather factors associated with water availability are especially important late in the season, but these factors differ between species: $S$. magellanicum $\mathrm{LI}$ correlates positively with precipitation, while $S$. angustifolium $\mathrm{LI}$ is positively affected by number of days with rain, i.e. rain frequency. Unlike S. magellanicum, S. angustifolium LI decreases when temperature rises late in the season, which suggests higher susceptibility to desiccation of this species. In previous field studies, Sphagnum LI has increased with higher rain frequency (Beckéus 1988; Robroek et al. 2009; Nijp et al. 2014; Krebs et al. 2016) and decreased withlonger rain free periods (Bengtsson et al. 2021). In our study, we show how weather factors simultaneously can have opposite effects on Sphagnum LI depending on species identity.

The dynamics of other functional traits are studied more on a spatial scale in connection to WT gradient (Laing et al. 2014; Bengtsson et al. 2016; Mazziotta et al. 2019), and they are often assumed to be constant on a temporal scale. Recent studies, nevertheless, have successfully attempted to find inter-year difference in moss carpet density (ND) (Graham and Vitt 2016; Bengtsson et al 2021). We find significant inter-year dynamics in ND of hummock species $S$. fuscum while $S$. magellanicum, S. angustifolium and $S$. fallax vary much less. Our interpretation is that while other species mainly govern stem growth, $S$. fuscum more actively controls carpet density depending on weather conditions. S. fuscum ND increases under the conditions of high moisture, and maybe stronger when combined with high temperature in the early season. In contrast, Bengtsson et al (2021) reported a negative effect of seasonal precipitation on ND across the Northern Hemisphere, but similar to our study they found a negative effect of mean temperature on ND. Dense carpet (i.e. high bulk density) maintains a high water retention in the late season when capillary moisture content is dropping in peat. High bulk density is crucial to maintaining a high water content (Bengtsson et al 2021; Nijp et al., 2014), and active branching of S. fuscum under favorable weather conditions will help to avoid future desiccation. Branching instead of elongation can be the way in which $S$. fuscum dominates in peatlands, but this needs further evidence.

The link between increment weight (IW) and capitulum weight (CW) to weather variables are weak in our study. Slowly changing weight traits (IW and CW) respond to integrated conditions of the growing season, which is in line with the finding of Laine et al. (2011) that weight increases after linear growth stops at the end of summer. However, we do not observe that late season variables are better predictors, with the exception of $S$. fallax CW.

\section{Habitat- and season-specific response of Sphagnum to weather factors}


The impact of the weather on Sphagnum growth depends on the local mire conditions, such as the current water table. For example, high temperature promotes the growth as long as peat moisture is high (Jassey and Signarbieux 2019). We found that temperature, precipitation and number of days with rain have the opposite effect on Sphagnum functional traits synchronously depending on the habitat, which is likely due to varying peat water availability. The water table drop often observed during the summer leads to a subsidence of peat in ecosystems with a water-surplus such as flarks and hollows (Nijp et al. 2019), while hummock height almost does not change with HWT fluctuation (Yazaki and Yabe 2012). In the study site of Bakchar mire, the HWT during the late growing season does not fall below $20 \mathrm{~cm}$ in the poor fen, but it noticeably drops in the raised bog (Dyukarev et al. 2015). Our results support the evidence that the same weather conditions promote moss desiccation and ceased growth in bogs, while it can promote moss growth in poor fens.

For bog species, mean temperature positively correlates with functional traits and productivity or it is insignificant in the early season, and it becomes indifferent or an inhibiting factor for growth in the late season. For the fen species, the opposite pattern is observed.

Precipitation, number of days with rain and length of the dry period are factors of water availability. "Number of days with rain" is a complex factor that includes temporal distribution of moisture, higher cloudiness and lower photosynthetically active radiation. There is evidence that the precipitation dependence of Sphagnum growth is high when the water table is deep (Nijp et al. 2014), but frequent daytime rain events reduce light and, consequently, decrease carbon uptake in peatlands (Nijp et al. 2015). Assuming that photosynthesis is more reduced by water availability than light, this effect on growth is more substantial when water table is closer to the moss surface like at our poor fen site. As a result, days with rain contribute to moss growth in bogs but decrease it in poor fens. "Length of the dry period" includes both moisture deficit and light availability. In the bog, this factor has a weak negative effect early in the season, and has no effect later in the season. In the poor fen, this factor is the driver of S. fallax LI and productivity augmentation as well as IW dropping.

Climatic index and precipitations at daily mean temperature above $15^{\circ} \mathrm{C}$ combine heat and moisture conditions. Such indices have previously been used to understand Sphagnum growth (e.g. Beckéus 1988; Asada et al 2003). The higher their value the more moisture is available at high temperature. In this study, climatic index is always positively correlates with growth in the bog but not in the poor fen. In the bog, precipitation at high temperature is always positive factor for Sphagnum growth with varying strength in different seasons. The only exception is found for $S$. fuscum $\mathrm{LI}$, which decreases with this factor. In the poor fen, moss growth is stimulated by this factor in the early season and it is inhibited in the late season. Combined climatic factors were the strongest predictors and showed higher importance early in the season or over the entire season.

Overall, thermal and moisture factors accelerate or inhibit Sphagnum growth depending on the period of the growing season, species and habitat. A switch from a positive correlation with a factor (e.g. mean temperature or length of the dry period) to a negative one during the growing season is the reason of 
weak or no relationship average for the entire season. This complexity has to be taken into account in peatland-climate modelling of Sphagnum productivity.

\section{Weather-induced inter-year difference in Sphagnum productivity and resistance of peat moss community}

There is evidence of similar productivity of Sphagnum across species over time due to a trade-off between maximizing length growth and maintaining high water content (Laing et al 2014; Mazziotta et al 2019; Bengtsson et al 2021, Jassey and Signarbieux 2019). In our study, inter-year range in ANP values is higher than in functional traits values for all studied species and this depended on changes in weather. Namely, S. fuscum and $S$. magellanicum were the most productive under warm and wet conditions with $S$. fuscum being less sensitive to weather fluctuations; $S$. angustifolium had highest productivity under cool and wet conditions; while $S$. fallax was the most productive under dry weather. What are the consequences of such contrasting species- and habitat-dependent (bog versus poor fen) weather effects on Sphagnum productivity for a mire complex? Total productivity of the dominant species in different habitats, S. fuscum and $S$. fallax, was stable over several years $\left(337 \pm 6 \mathrm{~g} \mathrm{~m}^{2} \mathrm{y}^{-1}\right)$ due to a strong negative linear correlation between the species productivity $(-0.93, p=0.022)$ over the period of 20132019 (Fig. 7). This implies complementary response of mosses to the same weather conditions, which induce both gain and decline in biomass depending on the habitat and species. Previously, evidences of Sphagna high functional diversity and intraspecific variability, which together indicate higher peatland resistance towards environmental perturbations have been reported (Laine et al. 2020). Here, on the temporal scale, we show intraspecific variability in peat moss responses to weather varying that is also indicates peatland resistance towards environmental inconstancy. Our finding is in accordance with the findings of Jassey and Signarbieux (2019), who showed stable ecosystem productivity with temperature changes due to the differential responses of Sphagnum species. Such complementary feedback between Sphagnum and weather fluctuations stabilises functioning of mire complexes regardless of meteorological conditions. Nevertheless, combinations of weather variables can cause a drop in the total productivity as observed in 2020 where a likely a combination of high frequency of rainy days (crucial for S. fallax) and moderate precipitation and low value of climatic index (crucial for $S$. fuscum) limited productivity (Fig. 7). To establish if such weather tipping points for mire productivity exists is an urgent task for future research.

Mutual replacement of Sphagnum productivity depending on weather can be found both within a mire ecosystem and between different mire types due to various dominant species. This study indicates that the predicted increase in temperature and drought periods (Moore 2002) are favourable for water-surplus mire ecosystems in Western Siberia, such as pools and lawns, in contrast to raised bogs and ridges in patterned mires. This is in contrast to the general idea that hummock species will be favoured over hollow/lawn species under climate change (e.g., Breeuwer et al. 2008; Robroek et al. 2009). Thus, there are still gaps in our understanding of which weather factors and of which magnitude cause shifts in peat mosses productivity, and subsequently, peat moss composition. Identifying critical ranges in climatic 
factors governing Sphagnum performance across climate zones is essential for predicting ecosystem change in a changing climate.

\section{Declarations}

\section{Funding:}

The research was made on field and laboratory equipment of the Institute of Soil Science and Agrochemistry, Siberian Branch of the Russian Academy of Sciences (ISSA SB RAS). The study was carried out according to the state assignment of ISSA SB RAS (for NGK, NPK, EAS, VAS, EKV).

\section{Competing interests:}

The authors have no conflicts of interest to declare that are relevant to the content of this article. The authors have no relevant financial or non-financial interests to disclose.

\section{Author's Contributions:}

Natalia P. Kosykh and Gustaf Granath outlined the study; Natalia G. Koronatova, Ekaterina A. Saib, Vera A. Stepanova, Evgenia K. Vishnyakova and Natalia P. Kosykh collected the data; Natalia G. Koronatova proposed the hypothesis, performed the data analysis and wrote the first draft of the manuscript; Gustaf Granath edited the manuscript; all authors reviewed and approved the manuscript.

\section{Data availability:}

The raw data are available via Mendeley Data repository [https://doi.org/10.17632/6d3sgzmdxp.2].

\section{Author's Contributions:}

Natalia P. Kosykh and Gustaf Granath outlined the study; Natalia G. Koronatova, Ekaterina A. Saib, Vera A. Stepanova, Evgenia K. Vishnyakova and Natalia P. Kosykh collected the data; Natalia G. Koronatova proposed the hypothesis, performed the data analysis and wrote the first draft of the manuscript; Gustaf Granath edited the manuscript; all authors reviewed and approved the manuscript.

\section{References}

1. Asada T, Warner BG, Banner A (2003) Growth of mosses in relation to climate factors in a hypermaritime coastal peatland in British Columbia, Canada. The Bryol 106(4):516-527. 
https://doi.org/10.1639/0007-2745(2003)106[516:GOMIRT]2.0.C0;2

2. Beckéus I (1988) Weather variables as predictors of Sphagnum growth on a bog. Holarct Ecol 11:146-150. https://doi.org/10.1111/j.1600-0587.1988.tb00793.x

3. Bengtsson F, Granath G, Rydin H (2016) Photosynthesis, growth, and decay traits in Sphagnum - a multispecies comparison. Ecol and Evol 6(10):3325-3341 https://doi.org/10.1002/ece3.2119

4. Bengtsson F, Granath G, Cronberg N, Rydin H (2020) Mechanisms behind species-specific water economy responses to water level drawdown in peat mosses. Ann Bot 20:1-

12. https://doi.org/10.1093/aob/mcaa033

5. Bengtsson F, Rydin H, Baltzer JL, Bragazza L, Bu Zh-J, Caporn SJM, Dorrepaal E, Flatberg KI, Galanina O, Gałka M, Ganeva A, Goia I, Goncharova N, Hájek M, Haraguchi A, Harris LI, Humphreys E, Jiroušek M, Kajukało K, Karofeld E, Koronatova NG, Kosykh NP, Laine AM, Lamentowicz M, Lapshina E, Limpens J, Linkosalmi M, Ma J-Z, Mauritz M, Mitchell EAD, Munir TM, Natali SM, Natcheva R, Payne RJ, Philippov DA, Rice SK, Robinson S, Robroek BJM, Rochefort L, Singer D, Stenøien HK, Tuittila E-S, Vellak K, Waddington JM, and Granath G (2021) Environmental drivers of Sphagnum growth in mires across the Holarctic region. J Ecol 109(1):417-431 https://doi.org/10.1111/13652745.13499

6. Breeuwer A, Heijmans MMPD, Robroek BJM, Berendse F (2008) The effect of temperature on growth and competition between Sphagnum species. Oecologia 156:155167. https://doi.org/10.1007/s00442-008-0963-8

7. Bu Zh-J, Rydin H, Chen X (2011) Direct and interaction-mediated effects of environmental changes on peatland bryophytes. Oecologia 166:555-563. https://doi.org/10.1007/s00442-010-1880-1

8. Bu Zh-J, Chen X, Rydin H, Wang Sh, Ma J, Zeng J (2013) Performance of four mosses in a reciprocal transplant experiment: implications for peatland succession in NE China. J Bryol 35(3):220227. https://doi.org/10.1179/1743282013Y.0000000063

9. Chapin FS III, Bret-Harte MS, Hobbie SE, Zhong H (1996) Plant functional types as predictors of transient responses of arctic vegetation to global change. J Veg Sci 7:347-358.

10. Clymo RS (1970) The growth of Sphagnum: methods of measurement. J Ecol 58(1):13-50.

11. Deane-Coe KK, Mauritz M, Celis G, Salmon V, Crummer KG, Natali SM, Schuur EAG (2015) Experimental warming alters productivity and isotopic signatures of tundra mosses. Ecosystems 18(6):1070-1082. https://doi.org/10.1007/s10021-015-9884-7

12. Dyukarev EA, Golovatskaya EA (2013) Temperature regime characteristics of the peat accumulation of the oligotrophic bog in the southern taiga of Western Siberia. Geography and Natural Res 13(1):65-71. http://izdatgeo.ru/journal.php? action=output_more\&id=3\&lang_num=1\&year=2013\&issue=1\&nodoi=1\&page=65

13. Dyukarev EA, Kurakov SA, Kharanzhevskaya YuA (2015) Differential pressure sensors for bog water level study (in Russian) Proceedings of the III International conf. "Problemy izucheniya i ispolzovaniya torfyanych resursov Sibiri” Stavropol, Alfa-Print:72-75 
14. Gignac LD, Vitt DH (1994) Responses of Northern peatlands to climate change: effects on bryophytes. J Hattori Bot Lab 75:119-

132. https://www.jstage.jst.go.jp/article/jhbl/75/0/75_119/_pdf

15. Gorham E (1991) Northern peatlands: role in the carbon cycle and probable responses to climatic warming. Ecol Appl 1(2):182-195. https://doi.org/10.2307/1941811

16. Grabovik SI, Nazarova LE (2013) Length increment of Sphagnum mosses on Karelian mires. Arctoa 22:23-26. https://doi.org/10.15298/arctoa.22.04

17. Graham JA, Vitt DH (2016) The limiting roles of nitrogen and moisture on Sphagnum angustifolium growth over a depth to water table gradient. Plant Soil 404:427439. https://doi.org/10.1007/s11104-016-2906-1

18. Granath G, Strengbom J, Rydin H (2010) Rapid ecosystem shifts in peatlands: linking plant physiology and succession. Ecology 91(10):3047-3056. https://doi.org/10.1890/09-2267.1

19. Gunnarsson U (2005) Global patterns of Sphagnum productivity. J Bryol 27:269279. https://doi.org/10.1179/174328205X70029

20. Hájek T (2009) Habitat and species controls on Sphagnum productivity and decomposition in a mountain raised bog. Boreal Environ Res 14:947958. http://www.borenv.net/BER/archive/pdfs/ber14/ber14-947.pdf

21. Hammer $\varnothing$, Harper DAT, Ryan PD (2001) PAST: Paleontological Statistics Software Package for Education and Data Analysis. Palaeontol Electronica 4(1):1-9 (Article 04). https://palaeoelectronica.org/2001_1/past/past.pdf

22. Hassel K, Kyrkjeeide MO, Yousefi N, Prestø T, Stenøien HK, Shaw JA, Flatberg KI (2018) Sphagnum divinum (sp. nov.) and S. medium Limpr. and their relationship to $S$. magellanicum Brid. J Bryol 40:197-222. https://doi.org/10.1080/03736687.2018.1474424

23. Hydrometeorological Center of Russia (2020) https://meteoinfo.ru Accessed 3 February 2020

24. Jassey VEJ, Signarbieux C (2019) Effects of climate warming on Sphagnum photosynthesis in peatlands depend on peat moisture and species-specific anatomical traits. Glob Change Biol 25(11):2859-3870. https://doi.org/10.1111/gcb.14788

25. Krebs M, Gaudig G, Joosten H (2016) Record growth of Sphagnum papillosum in Georgia (Transcaucasus): rain frequency, temperature and microhabitat as key drivers in natural bogs. Mires Peat 18:1-16 (Article 04). https://doi.org/10.19189/MaP.2015.0MB.190

26. Koronatova NG (2019) Temperature regime of fibrist histosols of the Bakchar mire (West Siberia) (in Russian). Pochvy i Okruzhayushchaya Sreda 2(3):e79. https://doi.org/10.31251/pos.v2i3.79

27. Kosykh NP, Koronatova NG, Naumova NB, Titlyanova AA (2008) Above- and below-ground phytomass and net primary productivity in boreal mire ecosystems of Western Siberia. Wetl Ecol Manag 16:139-153. https://doi.org/10.1007/s11273-007-9061-7

28. Kosykh NP, Koronatova NG, Granath G (2017 a) Effect of temperature and precipitation on length increment of Sphagnum fuscum and S. magellanicum in Western Siberia. Russian J Ecol 48(3):173181. https://doi.org/10.1134/S1067413617030080 
29. Kosykh NP, Koronatova NG, Lapshina ED, Filippova NV, Vishnyakova EK, Stepanova VA (2017 b) Linear growth and productivity of Sphagnum mosses in the middle taiga zone of West Siberia. Environ Dynamics Global Climate Change 8(1): 3-13. https://doi.org/10.17816/edgcc813-13

30. Küttim M, Küttim L, Ilomets M, Laine AM (2020 a) Controls of Sphagnum growth and the role of winter. Ecol Res 35:219-234. https://doi.org/10.1111/1440-1703.12074

31. Küttim M, Laine AM, Küttim L, Ilomets M, Robroek BJM (2020 b) Winter climate change increases physiological stress in calcareous fen bryophytes. Sci Total Environ 695:133867. https://doi.org/10.1016/j.scitotenv.2019.133867

32. Laine AM, Lindholm T, Nilsson M, Kutznetsov O, Jassey VEJ, Tuittila E-S (2021) Functional diversity and trait composition of vascular plant and Sphagnum moss communities during peatland succession across land uplift regions. J. Ecology 109:1774-1789. https://doi.org/10.1111/13652745.13601

33. Laine AM, Juurola E, Hájek T, Tuittila E-S (2011) Sphagnum growth and ecophysiology during mire succession. Oecologia 167:1115-1125. https://doi.org/10.1007/s00442-011-2039-4

34. Laing CG, Granath G, Belyea LR, Allton KE, Rydin H (2014) Tradeoffs and scaling of functional traits in Sphagnum as drivers of carbon cycling in peatlands. Oikos 123:817828. https://doi.org/10.1111/oik.01061

35. Lindholm T (1990) Growth dynamics of the peat moss Sphagnum fuscum hummocks on a raised bog in southern Finland. Annales Botanici Fennici 27:67-78.

36. Lindholm T, Vasander H. (1990) Production of eight species of Sphagnum at Suurisuo mire, southern Finland. Annales Botanici Fennici 27:145-157.

37. Loisel J, Gallego-Sala AV, Yu Z (2012) Global-scale pattern of peatland Sphagnum growth driven by photosynthetically active radiation and growing season length. Biogeosci 9:27372746. https://doi.org/10.5194/bg-9-2737-2012

38. Maksimov Al (1982) To the question of Sphagnum growth (in Russian). In: Lopatin VD, Yudina VF (Eds) Kompleksnye issledovaniya rastitelnosti bolot Karelii. Petrozavodsk: KB AS USSA:170-179.

39. Maseyk KS, Green TGA, Klinac D (1999) Photosynthetic responses of New Zealand Sphagnum species. New Zealand J Bot 37(1):155165. https://doi.org/10.1080/0028825X.1999.9512621

40. Mazziotta A, Granath G, Rydin H, Bengtsson F, Norberg J (2019) Scaling functional traits to ecosystem processes: towards a mechanistic understanding in peat mosses. J Ecol 107:843859. https://doi.org/10.1111/1365-2745.13110

41. Moore PD (2002) The future of cool temperate bogs. Environmental Conservation 29:3-20. https://doi.org/10.1017/S0376892902000024

42. Moore TR (1989) Growth and net productivity of Sphagnum at five fen sites, subarctic eastern Canada. Can J Bot 67:1203-1207. https://doi.org/10.1139/b89-156

43. Moore TR, Lafleur PM, Poon DMI, Heumann BW, Seaquist JM, Roulet NT (2006) Spring photosynthesis in a cool temperate bog. Glob Change Biol 12:2323- 
2335. https://doi.org/10.1111/j.1365-2486.2006.01247.x

44. Mulligan RC, Gignac LD (2001) Bryophyte community structure in a boreal poor fen: reciprocal transplants. Can J Bot 79:404-411. https://doi.org/10.1139/cjb-79-4-404

45. Nijp JJ, Metselaar K, Limpens J, Bartholomeus HM, Nilsson MB, Berendse F, Van Der Zee SEATM (2019) High-resolution peat volume change in a northern peatland: Spatial variability, main drivers, and impact on ecohydrology. Ecohydrol:e2114. https://doi.org/10.1002/eco.2114

46. Nijp JJ., Limpens J, Metselaar K, Peichl M, Nelsson MB, Van Der Zee SEATM, Berendse F (2015) Rain events decrease boreal peatland net $\mathrm{CO} 2$ uptake through reduced light availability. Global Change Biol 21:2309-2320. https://doi.org/10.1111/geb.12864

47. Nijp JJ, Limpens J, Metselaar K, Van Der Zee SEATM Berendse F, Robroek BJM (2014) Can frequent precipitation moderate the impact of drought on peatmoss carbon uptake in northern peatlands? New Phytol 203:70-80. https://doi.org/10.1111/nph.12792

48. Oke TA, Hager HA (2017) Assessing environmental attributes and effects of climate change on Sphagnum peatland distributions in North America using single-and multi-species models. PloS one 12(4):e0175978. https://doi.org/10.1371/journal.pone.0175978

49. Peregon AM, Maksyutov ShSh, Kosykh NP, Mironycheva-Tokareva NP (2008) Map-based inventory of wetland biomass and net primary productivity in western Siberia. J Geophys Res 113:G01007. https://doi.org/10.1029/2007JG000441

50. Raspisanie pogody (2019) https://rp5.ru/ Accessed 8 November 2019

51. Robroek BJM, Limpens J, Breeuwer A, Schouten MGC (2007) Effects of water level and temperature on performance of four Sphagnum mosses. Plant Ecol 190:97107. https://doi.org/10.1007/s11258-006-9193-5

52. Robroek BJM, Schouten MGC, Limpens J, Berendse F, Poorter H (2009) Interactive effects of water table and precipitation on net $\mathrm{CO} 2$ assimilation of three co-occurring Sphagnum mosses differing in distribution above the water table. Glob Change Biol 15:680-691. https://doi.org/10.1111/j.13652486.2008.01724.x

53. Robroek BJM, Jassey VEJ, Payne RJ, Martí M, Bragazza L, Bleeker A, Buttler A, Caporn SJM, Dise NB, Kattge J, Zając K, Svensson BH, van Ruijven J, Verhoeven JTA (2017) Taxonomic and functional turnover are decoupled in European peat bogs. Nat Commun

(8):1161 https://doi.org/10.1038/s41467-017-01350-5

54. Rohlf FJ and Corti M. 2000. Use of two-block partial least squares to study covariation in shape. Systematic Biology 49:740-753. DOI:10.1080/106351500750049806

55. Rydin H, Jeglum JK (2013) The biology of peatlands, $2^{\text {nd }}$ edn. Oxford: Oxford University Press.

56. Rydin H (1993) Interspecific competition between Sphagnum mosses on a raised bog. Oikos 66:413-423.

57. Schipperges B, Rydin H (1998) Response of photosynthesis of Sphagnum species from contrasting microhabitats to tissue water content and repeated desiccation. New Phytol 140:677- 
684. https://doi.org/10.1046/j.1469-8137.1998.00311.x

58. Smith LC, MacDonald GM, Velichko AA, Beilman DW, Borisova OK, Frey KE, Kremenetski KV, Sheng Y (2004) Siberian peatlands a net carbon sink and global methane source since the Early Holocene.

Science 33:353-356. https://doi.org/10.1126/science.1090553

59. Strack M Price JS (2009) Moisture controls on carbon dioxide dynamics of peat-Sphagnum monoliths. Ecohydrol 2:34-41. https://doi.org/10.1002/eco.36

60. Waddington JM, Morris PJ, Kettridge N, Granath G, Thompson DK, Moore PA (2015) Hydrological feedbacks in northern peatlands. Ecohydrol 8:113-127. https://doi.org/10.1002/eco.1493

61. Weltzin JF, Harth C, Bridgham SD, Pastor J, Vonderharr M (2001) Productivity and microtopography of bog bryophytes: response to warming and water-table manipulations. Oecologia 128:557565. https://doi.org/10.1007/s004420100691

62. Yazaki T, Yabe K (2012) Effects of snow-load and shading by vascular plants on the vertical growth of hummocks formed by Sphagnum papillosum in a mire of northern Japan. Plant Ecol 213:10551067. https://doi.org/10.1007/s11258-012-0065-x

\section{Tables}

\section{Table 1}

Values of weather variations (mean over 2013-2020 with the range given in parenthesis) during different periods of the growing season.

\begin{tabular}{|c|c|c|c|}
\hline \multirow[t]{2}{*}{ Weather variables } & \multicolumn{3}{|c|}{ Periods of the growing season } \\
\hline & $\begin{array}{l}\text { The early } \\
\text { season }\end{array}$ & $\begin{array}{l}\text { The late } \\
\text { season }\end{array}$ & $\begin{array}{l}\text { The entire } \\
\text { season }\end{array}$ \\
\hline Mean temperature $\left({ }^{\circ} \mathrm{C}\right)$ & $\begin{array}{l}14.0(12.7- \\
17.4)\end{array}$ & $\begin{array}{l}15.9(14.2- \\
17.1)\end{array}$ & $\begin{array}{l}15.0(14.0- \\
15.7)\end{array}$ \\
\hline Sum of temperatures $\left({ }^{\circ} \mathrm{C} \cdot\right.$ days $)$ & $\begin{array}{l}738(437- \\
1027)\end{array}$ & $\begin{array}{l}1182(1054- \\
1385)\end{array}$ & $\begin{array}{l}1919(1537- \\
2352)\end{array}$ \\
\hline Precipitation (mm) & $121(59-197)$ & $142(81-192)$ & $263(140-347)$ \\
\hline $\begin{array}{l}\text { Precipitation at mean daily temperature above } \\
15^{\circ} \mathrm{C}(\mathrm{mm})\end{array}$ & $41(1-116)$ & $78(39-163)$ & $118(51-215)$ \\
\hline Climatic index & $\begin{array}{l}44.2(21.1- \\
116.5)\end{array}$ & $\begin{array}{l}37.0(25.5- \\
51.0)\end{array}$ & $\begin{array}{l}37.7(24.7- \\
61.5)\end{array}$ \\
\hline Number of days with rain (days) & $24(12-37)$ & $30(22-50)$ & $54(34-87)$ \\
\hline Length of dry period (days) & $10(0-29)$ & $16(6-27)$ & $26(15-56)$ \\
\hline
\end{tabular}


Pearson's correlation between ANP and functional traits. Significant correlations are given in bold.

\begin{tabular}{|llll|}
\hline Species & Linear increment & Increment weight & Numerical density \\
\hline S. fuscum & $0.08(P=0.87)$ & $\mathbf{0 . 8 4}(\boldsymbol{P}=\mathbf{0 . 0 1 9 3})$ & $0.43(P=0.33)$ \\
\hline S. magellanicum & $\mathbf{0 . 9 2 ( P = \mathbf { 0 . 0 0 1 3 } )}$ & $\mathbf{0 . 8 6}(\boldsymbol{P}=\mathbf{0 . 0 0 6 3 )}$ & $\mathbf{0 . 9 5}(\boldsymbol{P}=\mathbf{0 . 0 0 0 3})$ \\
\hline S. angustifolium & $\mathbf{0 . 9 0 ( P = \mathbf { 0 . 0 1 5 9 } )}$ & $-0.07(P=0.88)$ & $0.15(P=0.75)$ \\
\hline S. fallax & $\mathbf{0 . 9 4 ( P = \mathbf { 0 . 0 0 1 7 } )}$ & $-0.27(P=0.56)$ & $-0.23(P=0.62)$ \\
\hline
\end{tabular}

Figures 

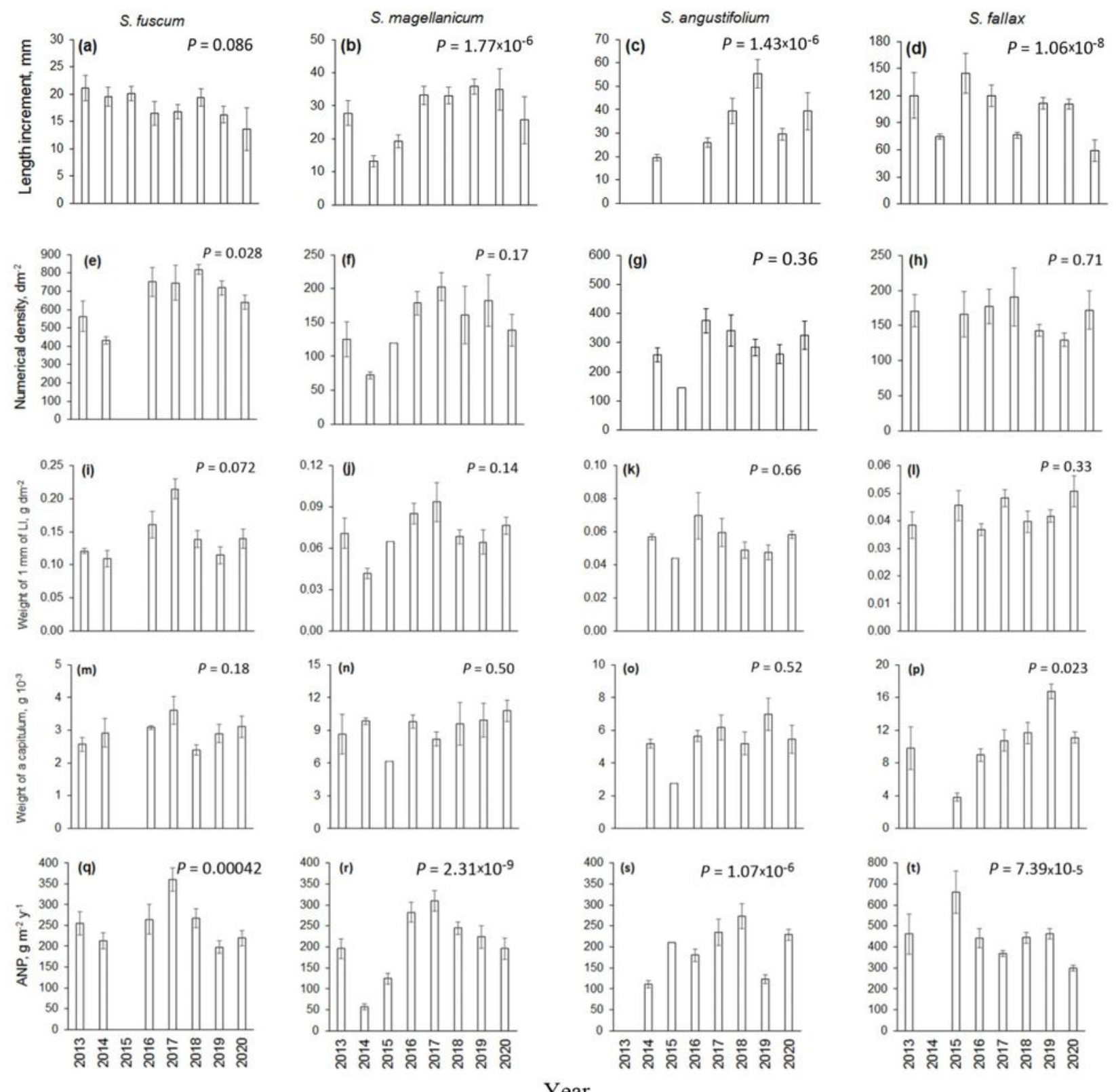

Year

Figure 1.

\section{Figure 1}

Mean yearly values of length increment (a-d; $n=12-14,10-18,6-30$ and 3-23, respectively), numerical density (e-h; $n=3-5,1-5,1-4$ and 3-5, respectively), increment weight (i-l; $n=3-5,1-5,1-4$ and 3-5, respectively), capitulum weight ( $m-p ; n=3-5,1-5,1-4$ and $3-5$, respectively), and primary productivity (q-t; $n$ $=12-14,10-18,1-30$ and 3-23, respectively) in four Sphagnum species. Bars show means \pm SE. No bars 
indicates absence of replicates. Results of non-parametric Kruskal-Wallis test on inter-year differences are shown as $P$ values.

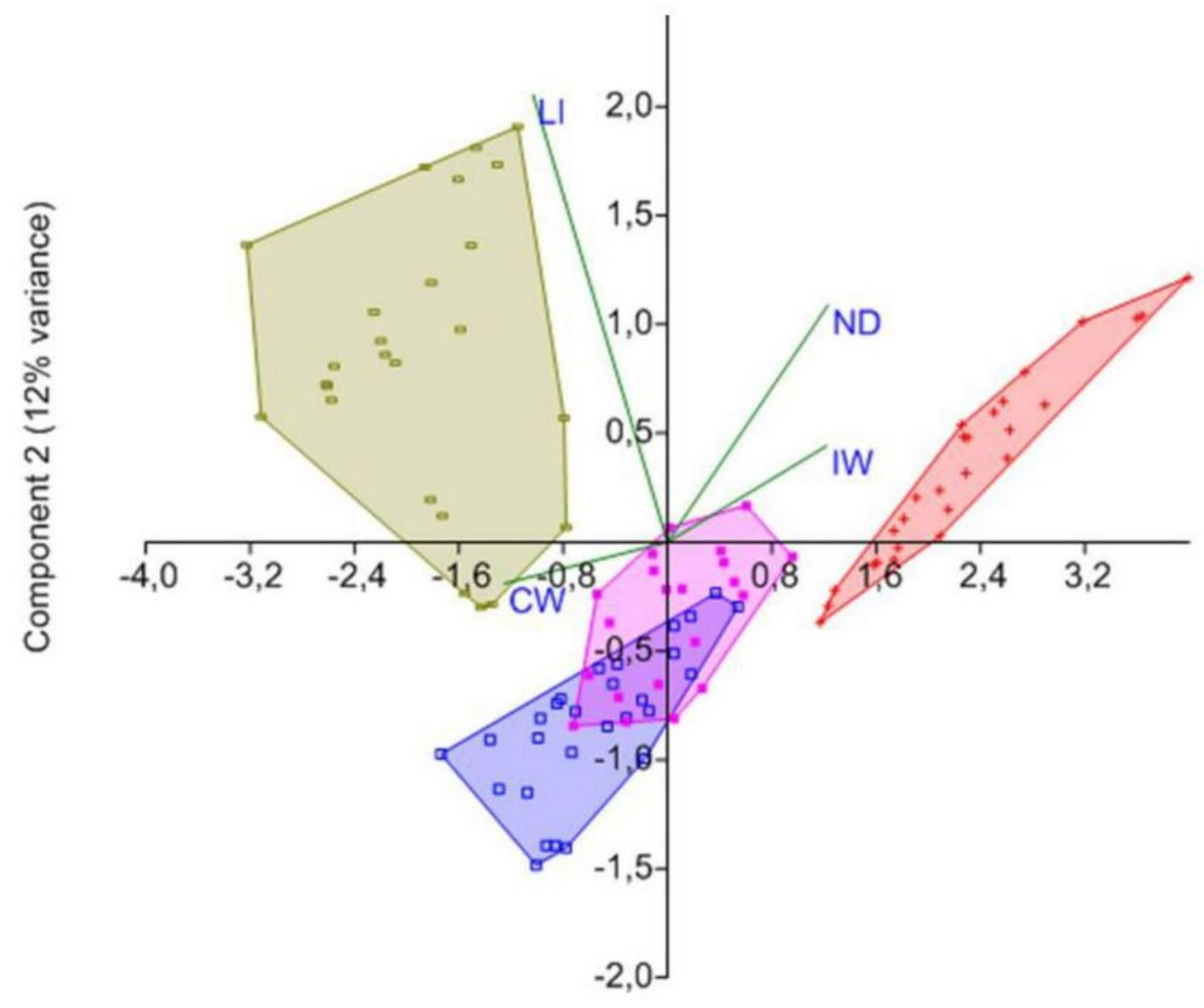

Component 1 (83\% variance)

\section{Figure 2.}

\section{Figure 2}

Ordination of weather variables - Sphagnum traits over the entire season based on principal components analysis. The species are shown with convex hulls: red - Sphagnum fuscum, blue - S. magellanicum, pink 
- $S$. angustifolium and greeny grey - $S$. fallax. The abbreviations of weather variables: $T_{m}-$ mean temperature, $\mathrm{Pr}$ - precipitation, $\operatorname{Pr}_{\mathrm{T} 15}$ - precipitation at mean daily temperature above $15^{\circ} \mathrm{C}, \mathrm{Cl}$ - climatic index, RD - number of days with rain, DD - length of dry period. The abbreviations of trait variables: LI linear increment, IW - increment weight, ND - numerical density and CW - capitulum weight
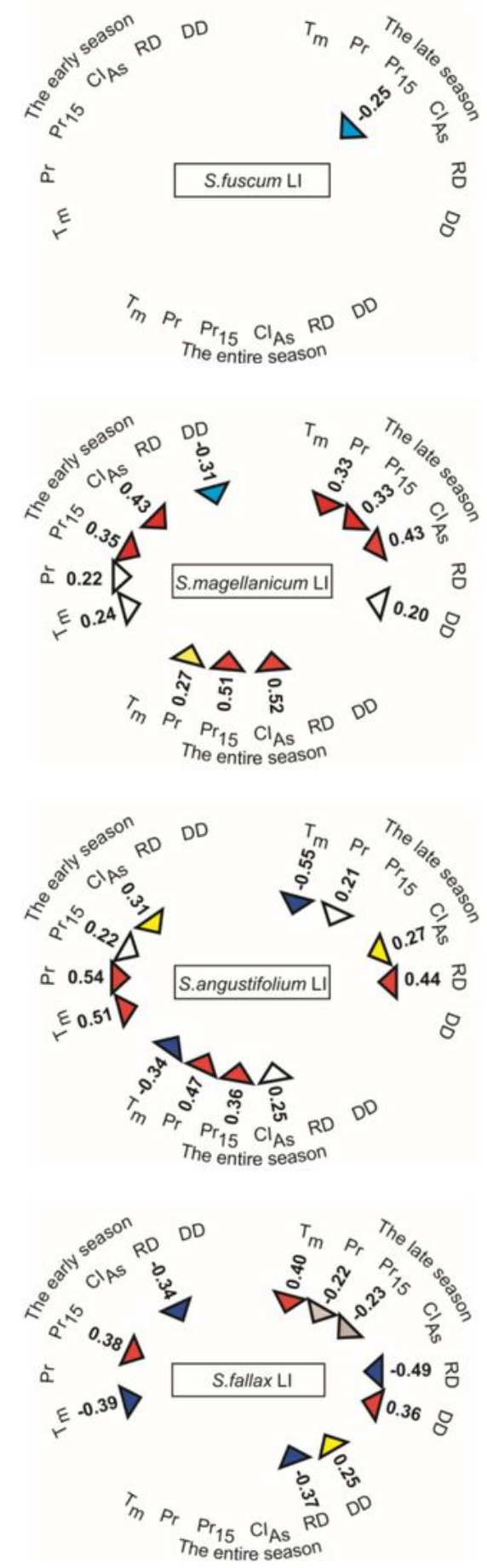

Figure 3.

\section{Figure 3}


Spearman's correlation between Sphagnum length increment (LI) and weather variables over the early season, the late season and the entire growing season. Arrows of different colours indicate significance. For positive correlations, red means $P<0.001$, yellow means $P<0.01$ and white means $P<0.05$. For negative correlations dark blue means $P<0.001$, blue means $P<0.01$ and grey means $P<0.05$. Absence of arrow means that the correlation is not significant $(P>0.05)$. The abbreviations of weather variables: $\mathrm{T}_{\mathrm{m}}$ - mean temperature, $\mathrm{Pr}$ - precipitation, $\mathrm{Pr}_{\mathrm{T} 15}$ - precipitation at mean daily temperature above $15^{\circ} \mathrm{C}$, $\mathrm{Cl}_{\mathrm{As}}$ - climatic index, $\mathrm{RD}$ - number of days with rain, $\mathrm{DD}$ - length of dry period. Details on correlations are given in Supplementary materials (Appendix Table S11) 

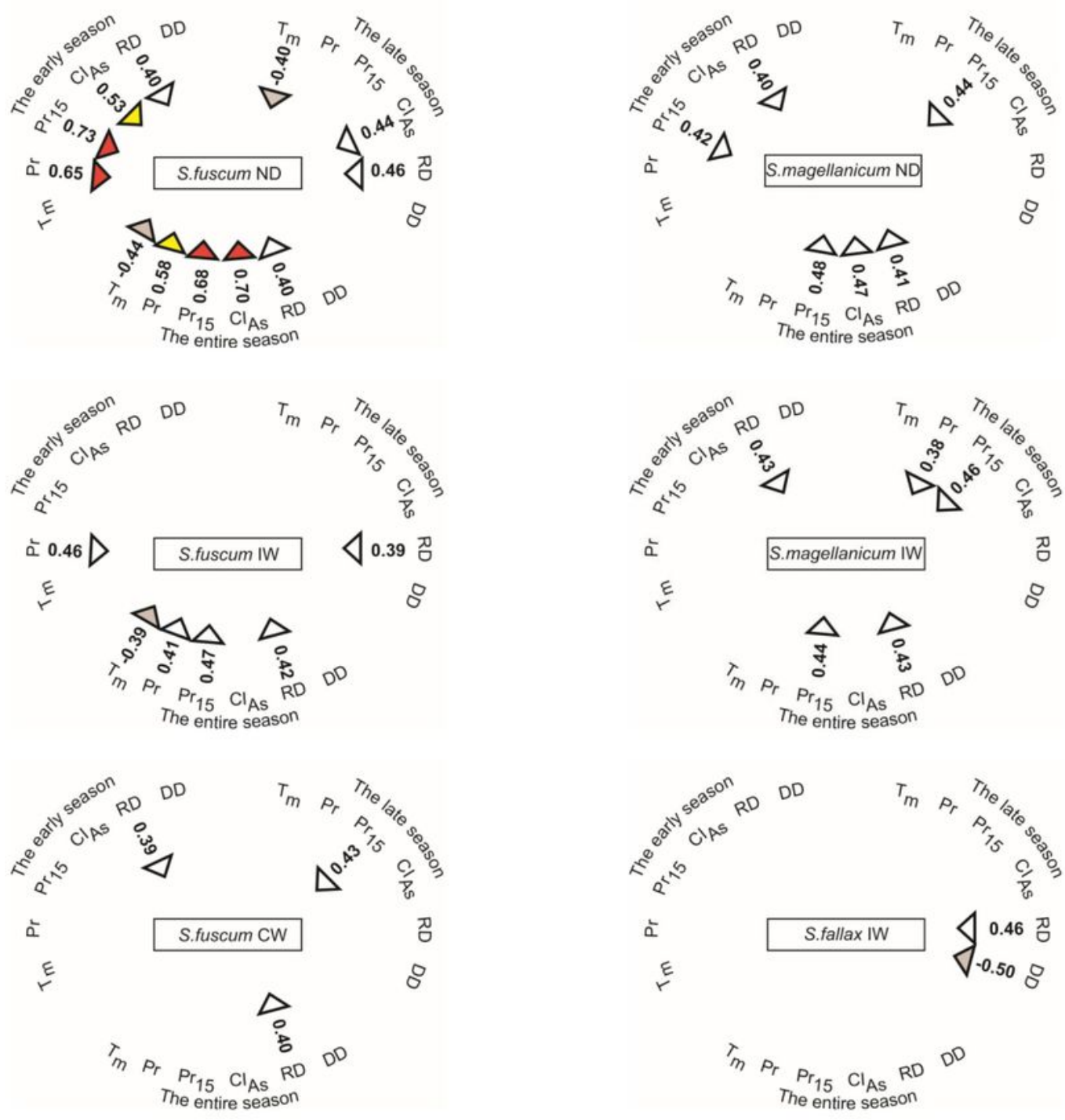

Figure 4.

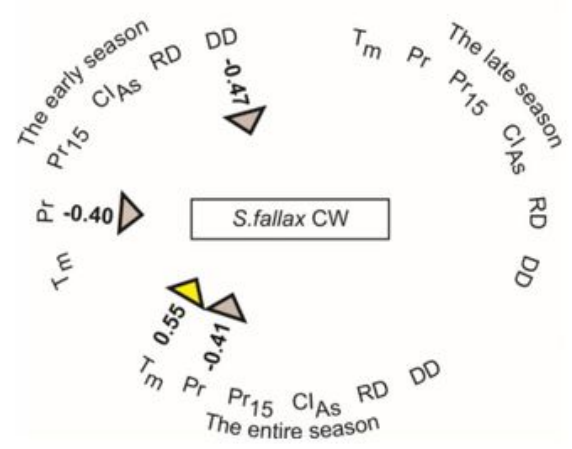

\section{Figure 4}

Spearman's correlations between Sphagnum numerical densities (ND), increment weights (IW), capitulum weight (CW) and weather variables over the early season, the late season and the entire growing season. Arrows of different colours indicate significance. For positive correlations, red means $P<0.001$, yellow means $P<0.01$ and white means $P<0.05$. For negative correlations dark blue means $P<0.001$, blue means $P<0.01$ and grey means $P<0.05$. Absence of arrow means that the correlation is not significant 
$(P>0.05)$. No significant correlations were found for $S$. magellanicum $\mathrm{CW}, S$. fallax ND and functional traits of $S$. angustifolium. The abbreviations of weather variables: $\mathrm{T}_{\mathrm{m}}-$ mean temperature, $\mathrm{Pr}-$ precipitation, $\mathrm{Pr}_{\mathrm{T} 15}$ - precipitation at mean daily temperature above $15^{\circ} \mathrm{C}, \mathrm{Cl}_{\mathrm{As}}$ - climatic index, $\mathrm{RD}-$ number of days with rain, DD - length of dry period. Details on correlations are given in Supplementary materials (Appendix Table S12, S13, S14)
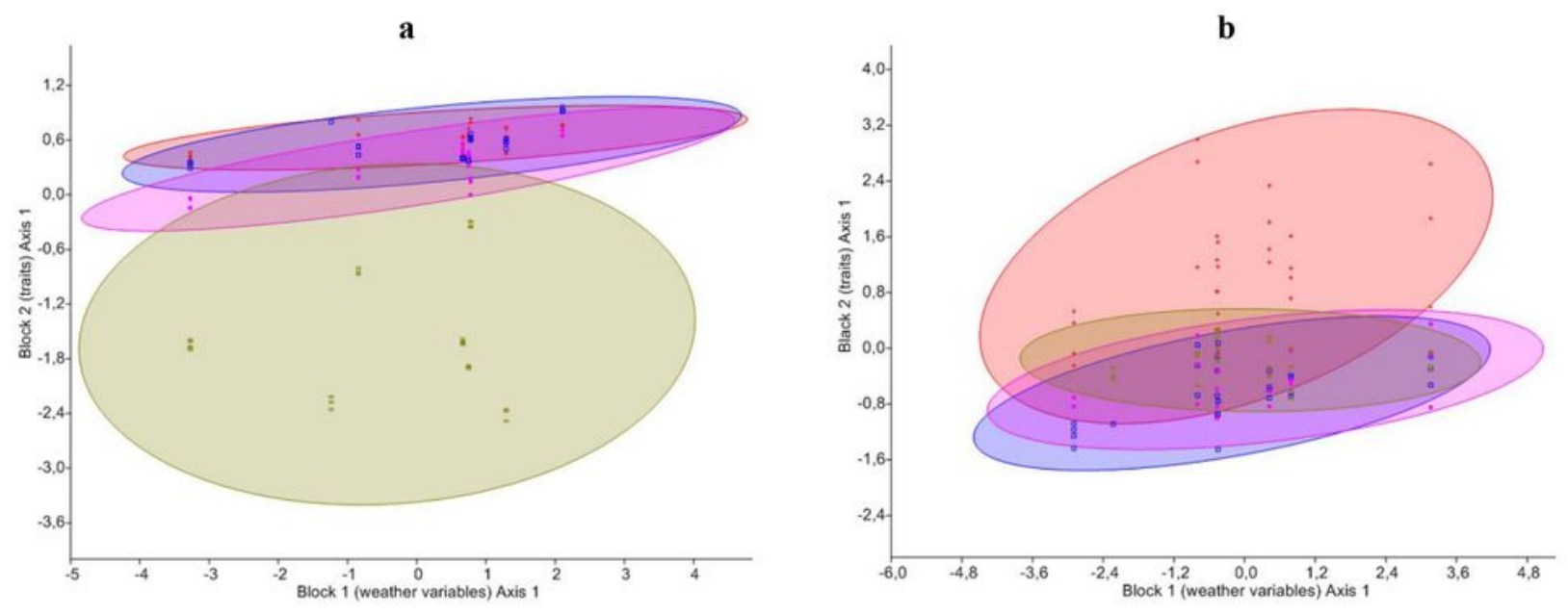

c

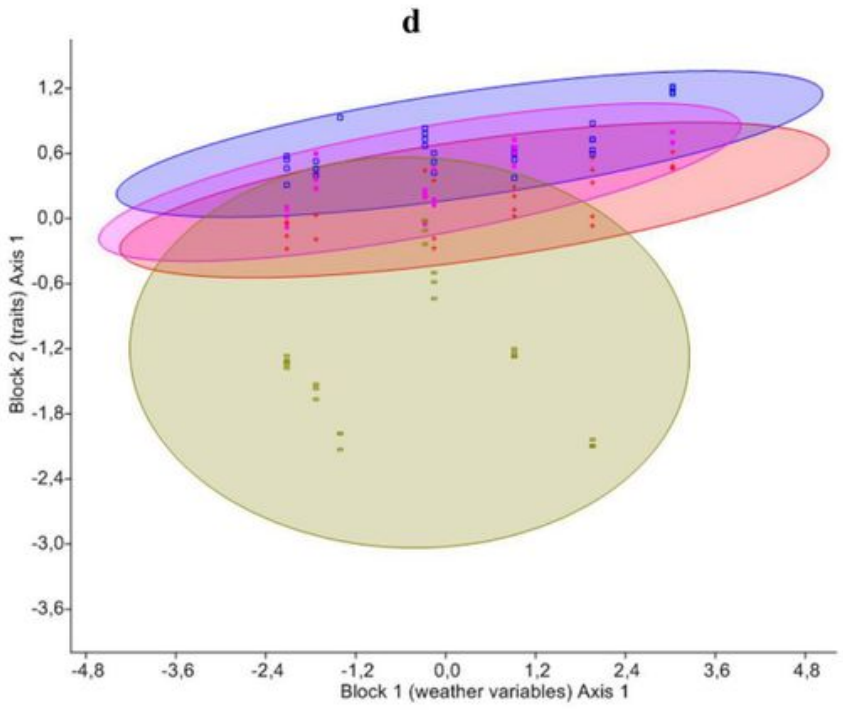

Figure 5.

Figure 5 
Plots of the two-block partial least squares (PLS) analysis with weather variables (block 1) against traits (block 2): a) The early season: the amount of covariance explained by the Axis 1 (the first block) is $83 \%$ with the most component loadings of precipitation $(-0.67)$, precipitation at mean daily temperature above $15^{\circ} \mathrm{C}(-0.57)$ and climatic index $(-0.42)$; b) The late season: the amount of covariance explained by the Axis 1 (the first block) is $50 \%$ with the most component loadings of climatic index (0.73), precipitation (0.49) and precipitation at mean daily temperature above $15^{\circ} \mathrm{C}(0.42)$; $\mathrm{c}$ ) The late season: the amount of covariance explained by the Axis 2 (the first block) is $46 \%$ with the most component loadings of length of dry period (-0.63), mean temperature $(0.56)$ and precipitation at mean daily temperature above $15^{\circ} \mathrm{C}$ $(0.42)$; d) The entire season: the amount of covariance explained by the Axis 1 (the first block) is $82 \%$ with the most component loadings of precipitation (-0.67), climatic index (-0.42), mean temperature (0.42) and precipitation at mean daily temperature above $15^{\circ} \mathrm{C}(-0.39)$. Species are marked with coloured $95 \%$ confidence interval ellipses: red - Sphagnum fuscum, blue - S. magellanicum, pink - S. angustifolium and greeny grey $-S$. fallax

\section{Figure 6}

Spearman's correlations between Sphagnum ANP and weather variables over the early season, the late season and the entire growing season. Arrows of different colours indicate significance. For positive correlations, red means $P<0.001$, yellow means $P<0.01$ and white means $P<0.05$. For negative correlations dark blue means $P<0.001$, blue means $P<0.01$ and grey means $P<0.05$. Absence of arrow means that the correlation is not significant $(P>0.05)$. The abbreviations of weather variables: $\mathrm{T}_{\mathrm{m}}-$ mean temperature, $\mathrm{Pr}$ - precipitation, $\mathrm{Pr}_{\mathrm{T} 15}$ - precipitation at mean daily temperature above $15^{\circ} \mathrm{C}, \mathrm{Cl}_{\mathrm{As}}-$ climatic index, RD - number of days with rain, DD - length of dry period. Details on correlations are given in Supplementary materials (Appendix Table S15)

\section{Figure 7}

The total productivity of the dominant species in bogs (S. fuscum, blue) and poor fens (S. fallax, yellow)

\section{Supplementary Files}

This is a list of supplementary files associated with this preprint. Click to download.

- Supplementarymaterial3.docx 